\title{
The Relationship between Duration of Benzene Exposure with Liver Enzymes in Car Painting Workshop Workers
}

\author{
Hubungan antara Durasi Paparan Benzena dengan Enzim Hati pada Pekerja \\ Pengecatan Mobil
}

\author{
Fitri Yatulaini ${ }^{1}$, Abdul Rohim Tualeka ${ }^{2}$, Juliana Jalaludin ${ }^{3}$, Syamsiar S Russeng ${ }^{4}$ \\ 1,2,3 Department of Occupational Health and Safety, Faculty of Public Health, Universitas Airlangga \\ Campus C Mulyorejo, Surabaya 60115 East Java, Indonesia \\ ${ }^{3}$ Department of Environmental and Occupational Health, Faculty of Medicine and Health Sciences, \\ University Putra Malaysia \\ Faculty of Medicine and Health Sciences, 43400 UPM Serdang, Selangor Darul Ehsan \\ ${ }^{4}$ Department of Occupational Health and Safety, Faculty of Public Health, Hassanudin University \\ Jalan Perintis Kemerdekaan KM. 10, Tamalanrea, 90245 Makassar, Indonesia
}

\begin{abstract}
Introduction: Benzene is a carcinogenic compound that can be found in a car painting workshop in Surabaya. The source of benzene in the car painting workshop comes from thinners. Inhalation is the main route for benzene to enter the body. The duration of benzene exposure can affect the accumulation of benzene concentrations. If work safety is not considered, the benzene compound can cause the liver disease. Furthermore, SGOT and SGPT are basic parameters of liver function. The study aims to determine the relationship between the duration of benzene exposure with SGOT and SGPT levels in car painting workshop workers. Method: observational research with a cross-sectional approach was applied as the method of this study. The research was conducted in a car painting workshop in 2019 with 20 workers. The variables were the duration of benzene exposure (hours/day) and levels of SGOT and SGPT. Data analysis used the Fisher's Exact Test and Coefficient Contingency test. Results: Workers worked with a duration of benzene exposure $\leq 8$ hours/day by $70 \%$ and $>$ 8 hours/day by $30 \%$. The measurement results exceeded the normal limit with the value of SGOT of $15 \%$ and the SGPT of $30 \%$. Furthermore, the Sstatistical test show p-values between the duration of benzene exposure and SGOT (0.202) and SGPT (0.303), body weight with SGOT (1.000) and SGPT (1.000), education with SGOT (0.199) and SGPT (0.182) and alcohol consumption with SGOT (1.000) and SGPT (1.000). Conclusion: There was no relationship between the duration of benzene exposure with SGOT and SGPT levels in car painting workshop workers in Surabaya with a p-value $>0.05$.
\end{abstract}

Keywords: car painting workers, duration of benzene exposure, SGOT, SGPT

\section{ABSTRAK}

Pendahuluan: Benzena merupakan senyawa karsinogenik yang dapat ditemukan di Bengkel pengecatan mobil di Surabaya. Sumber benzena di Bengkel pengecatan mobil berasal dari tiner. Inhalasi merupakan rute utama benzena dapat masuk kedalam tubuh. Durasi paparan benzena dapat menyebabkan akumulasi konsentrasi benzena. Jika keselamatan kerja tidak diperhatikan, senyawa benzena dapat menyebabkan penyakit hati. SGOT dan SGPT merupakan parameter dasar fungsi hati. Penelitian bertujuan untuk mengetahui hubungan antara durasi paparan benzena dengan kadar SGOT dan SGPT pada pekerja bengkel pengecatan mobil. Metode: Penelitian observasional dengan pendekatan cross- sectional sebagai metode didalam penelitian. Penelitian dilakukan di Bengkel pengecatan mobil di Surabaya pada tahun 2019 dengan jumlah 20 pekerja. Variabel dalam penelitian ini yaitu durasi paparan benzena (jam/hari), kadar SGOT dan SGPT. Analisis data menggunakan uji Fisher's Exact. Hasil: Pekerja bekerja dengan durasi paparan $\leq 8$ jam/hari sebesar $70 \%$ dan $>8$ jam/hari sebesar 30\%. Hasil pengukuran melebihi batas normal pada SGOT sebesar 15\% dan SGPT 30\%. Uji statistic menunjukkan p-value antara durasi paparan benzene dengan SGOT $(0,202)$ dan SGPT $(0,303)$, berat badan dengan SGOT (1,000) dan SGPT (1,000), Pendidikan dengan SGOT (0,199) dan SGPT $(0,182)$ serta konsumsi alcohol dengan SGOT (1,000) dan SGPT (1,000). Simpulan: tidak terdapat hubungan antara durasi paparan benzena dengan kadar SGOT dan SGPT pada pekerja bengkel pengecatan mobil di Surabaya dengan p-value >0,05.

Kata kunci: durasi paparan benzene, pekerja pengecatan mobil, SGOT, SGPT

Corresponding Author:

Abdul Rohim Tualeka

Email: abdul-r-t@fkm.unair.ac.id

Telephone: +62 81333519732

(C2021 IJOSH All right reserved. Open access under CC BY NC-SA license doi:10.20473/ijosh.v10i3.2021.361-370 Received July 09, 2021, received in revised form September 22, 2021, Accepted September 22, 2021, Published: December 2021 


\section{INTRODUCTION}

Every job must pay attention to occupational safety and health aspects in order to avoid occupational diseases and work-related accidents which can arise from a hazard. Hazards are potential sources of harm which are divided into a health hazard and safety hazard. Safety hazard is a type of hazard that has effect on accidents that can cause property damage, injury to workers, and even death; the impact is acute. Meanwhile, a health hazard is a type of hazard that has an effect on health; the impact is chronic (Sari and Suryani, 2018). A safety hazard is synonymous with work-related accidents, and a health hazard is synonymous with occupational diseases. According to the International Labor Organization, every year there are workers who die (2.78 millions) due to work accidents and occupational diseases. If classified, there are 2.4 million workers $(86.3 \%)$ who died due to work-related diseases (occupational diseases) (Hämäläinen, Takala and Kiat, 2017).

Occupational diseases are less noticed when compared to work-related accidents because they have a chronic nature, which means it take a long time to be identified. Occupational diseases are often more associated with health hazards. One type of health hazard is a chemical hazard which can enter through skin contact or inhalation (NIOSH, 2019). Benzene is a chemical compound in the carcinogenic category that can be harmful to the body. In addition, benzene is a compound at Volatile Organic Compounds (VOCs) which can easily enter the body (Aksoy, 2017). Benzene is a toxic substance that can cause various disease disorders. Some of the symptoms due to benzene exposure are symptoms of nervous disorders, upper respiratory symptoms, cough, joint pain, heart symptoms, dermatological symptoms, gastro intestinal symptoms, diarrhea, visual symptoms and vomiting (D'Andrea and Reddy, 2018).

There are two ways to obtain benzene, namely natural processes and human activities. The sources of benzene in natural processes are petroleum, volcanic gas emissions, and forest fire, while the sources of benzene in human activities are the emission of vehicles used (cars and motorcycles), smoking, and work products containing benzene (CDC, 2018). Benzene is the most commonly encountered compound in industry, both as a primary substance or as an additive. A national survey in Japan revealed that more than 1000 samples of products such as paints, thinners, inks, and adhesives collected from various industries contained benzene (Aksoy, 2017). There are two types of industry, namely formal and informal. In Indonesia, the informal industry is an industry that still dominates, followed by an increase in the number of workers. According to the Central Bureau of the Statistics of the Republic of Indonesia, in August 2020 there was an increase in the workforce within one year of $4.59 \%$ with the number of workers reaching 77.68 (Statistics Indonesia, 2020).

Benzene with the compound formula $\mathrm{C}_{6} \mathrm{H}_{6}$ has several other properties such as flammable, carcinogenic, and easily soluble in alcohol, chloroform, ether, acetone, and organic solvents (Aksoy, 2017). Car painting workshops are an informal industry that cannot be separated from exposure to benzene. Benzene content comes from thinner that is a paint additive for better results and one of the organic solvents. Thus, safe work for workers in the car painting workshop industry needs attention. Benzene is a health hazard that can lead to various types of diseases and can cause cancer in workers when they are exposed for years (NIOSH, 2019). In addition, according to the CDC (2018), exposure to benzene within a few minutes causes drowsiness, dizziness, fast or irregular heartbeat, headache, shaking, and confusion, while prolonged exposure can cause unconsciousness and death. This condition needs serious attention because a long duration causes a higher concentration of benzene in the body.

The owners of a industry are required to know about the permissible threshold value of chemical substances. Each chemical substance has a different threshold value. In Indonesia, there are several regulations regarding benzene exposure, such as the Minister of Manpower No 05 of 2018 which stated that the TLV of benzene is $0.5 \mathrm{ppm}$. In addition, the Minister of Health No 70 of 2016 mentioned the TLV of benzene in the work environment is $0.5 \mathrm{ppm}$ with a time of exposure of no more than 8 hours/ day or 40 hours/week. Internationally, NIOSH is the first reference to standards for benzene exposure promulgated by the Occupational Safety and Health Administration (OSHA), which stated that the permissible exposure to benzene (PEL) is $1 \mathrm{ppm}$ for no more than 8 hours and the Short Term Exposure Limit (STEL) is $5 \mathrm{ppm}$ for less than 15 minutes (NIOSH, 2019).

Benzene is a toxic substance that can cause health problems. According to Aksoy (2017), there are 3 factors that influence health problems 
due to benzene exposure, namely concentration, duration of exposure and route of entry. Inhalation, ingestion, and skin are the three routes of benzene. The concentration of benzene is divided into two, namely in the air and in the body which has turned into benzene metabolites. Inhalation is the main route of benzene. That matters because benzene is a substance classified as VOC while it simply evaporates and enters the body through the respiratory system (inhalation). The benzene route is a factor that needs to be considered because it affects the toxic kinetics of benzene. In general, symptoms of toxicity occur after inhalation of high doses of benzene (3000 ppm for 5 minutes) and 3060 minutes after ingestion (CDC, 2018).

Time is a factor that needs to be considered because this has also been confirmed in the Minister of Health No 70 of 2016. The duration of benzene exposure can affect the accumulation of benzene in the body. The duration of benzene that is overlong causes the concentration of benzene in the body to be higher (Bestari, Sudarmaji and Sulistyorini, 2019). The long duration of benzene is not safe for workers because it can cause various health problems. Research by Martínez-rodríguez et al. (2018).which examined the damage in various organs due to exposure to benzene showed that the liver was the worst organ affected. This should be given great attention due to the high reaction rate between free radicals and toxic metabolites of benzene with biomolecules. Factors that influenced the damage due to the high reaction were dose and exposure time.

Benzene is a compound that will enter the body's metabolic system. The main organs in the system of metabolism of toxic substances are the liver and CYP enzymes. About $80 \%$ of the metabolic system of toxicant substances depends on CYP enzymes, especially the CYP2E1 type ( $\mathrm{Lu}$, Shahbaz and Winn, 2020). Toxic benzene will be oxidized with the help of the CYP2E1 enzyme into free radicals in the form of benzene oxide (Aksoy, 2017). An increase in CYP2E1 means that there is also an increase in oxidative stress which has an impact on liver cell damage (Tirosh, 2015). In addition, the duration of benzene exposure is also a contributing factor to the increase in free radicals that can cause hepatocellular injury.

Diseases caused by benzene compounds are classified as occupational diseases that have a chronic nature. Chronic is a disease term that occurs over a long period. Therefore, the examination as early as possible needs to be done. Several studies such as Fayed, Saleh and Aly (2017) research comparing exposure and control workers stated that benzene-exposed workers had a significant increase in liver enzymes. Liver function disorders due to benzene can be seen from the parameters, which are SGOT and SGPT (Setyawati and Anggraeni, 2018). Research Zeverdegani, Barakat and Yazdi (2016) showed the differences in workers' liver enzymes due to exposure to BTX (benzene, toluene, xylene), namely $\mathrm{SGOT}=29.56 \pm 9.49$ and $\mathrm{SGPT}=38.67 \pm$ 17.5 , which were greater than the values in workers who were not exposed to benzene, namely SGOT $=$ $17.5 \pm 6.38$ and SGPT $=21.11 \pm 8$. The Indonesian Ministry of Health stated that the normal limit for SGOT is 5-40 U/L while for SGPT the normal limit is $5-35 \mathrm{U} / \mathrm{L}$.

The liver is an important organ in the body that has many roles such as in the digestive system, excretory system, a gland and detoxification (Alfadaly et al., 2016). The liver injury will be characterized by increased levels of SGOT and SGPT in the blood. Research conducted on rats with different time durations showed that there was an increase in SGOT and SGPT levels with a duration of 4 hours/day of exposure compared to a duration of 1 and 2 hours/day (Alshareef and Ibrahim, 2020). Another study conducted on gas station workers with an average duration of exposure of 12 hours/ day showed significant results in increasing levels of SGOT and SGPT (Alshareef and Ibrahim, 2020b). The aim of this present study is to determine the relationship between duration of benzene (hours/ day) with levels of SGOT and SGPT in car painting workers in Surabaya.

\section{METHODS}

The study was an observational study using a quantitative approach with a cross sectional design. The research was conducted in October 2019 in a car painting workshop in Surabaya with 20 male workers. There were 2 variables used in this study, namely the independent variable and the dependent variables. The independent variable in this study was the duration of benzene exposure in hours/day and the dependent variables in this study were SGOT and SGPT levels in workers. Data were collected in several ways including questionnaires, measurement of benzene concentrations and blood sampling of workers which was is carried out on the working day of the final shift for the measurement of SGOT 
and SGPT levels. A questionnaire was used to see the characteristics of workers and the duration of benzene exposure while at work. Measurement of benzene concentrations using the NIOSH 1501 method with gas chromatography techniques was carried out by the Technical Implementation Unit for Occupational Safety and Health. Meanwhile, measurements of SGOT and SGPT levels were conducted by taking blood samples of workers. Blood samples were carried out by the nutrition laboratory team of Universitas Airlangga as much as $5 \mathrm{cc}$. The workers' blood samples that had been collected would be taken to the nutrition laboratory of Universitas Airlangga for examination. The method used in the examination of SGOT and SGPT was the enzymatic kinetic method with a semiautomatic photometer 4010 which was carried out in accordance with The International Federation of Clinical Chemistry and Laboratory Medicine (IFCC). Afterwards, data were analyzed using Fisher's Exact Test and Coefficient Contingency Test. This study was approved by the institutional Ethical Board of the Public Health, Universitas Airlangga University with the ethic certificate number 605/HRECCFODM/IX/2019. In ethics it is explained that the duration of exposure to benzene is the length of exposure to benzene during work in units of hours/day.

\section{RESULTS}

A total respondent in this study was 20 male workers with an age range of 16-58 years old. Although all workers were males, the characteristics of each worker were different. Table 1 shows the characteristics of workers in a car painting workshop in Surabaya. The results of table 1 show that the majority of workers weighed $>55 \mathrm{~kg}(60 \%)$. In addition, table 1 shows the education of the respondents indicating that there were 2 people $(10 \%)$ with elementary school education, and 9 people each with junior high school and senior high school education. Jobs that required accuracy also made the majority of workers also not consume alcohol (95\%).

The Minister of Health No 70/2016 stated that the duration of benzene exposure is not more than 8 hours/day or 40 days/week because these substances can cause health problems. In this study the duration of benzene exposure was divided into $\leq 8$ hours/day and $>8$ hours/day. Table 2 shows that some workers worked for 8 hours/day accounting for $70 \%$ and
Table 1. Characteristics of the Respondents in a Car Painting Workshop in Surabaya 2019

\begin{tabular}{|c|c|c|}
\hline $\begin{array}{l}\text { Characteristics of } \\
\text { Respondents }\end{array}$ & Frequency (n) & Percentage (\%) \\
\hline \multicolumn{3}{|c|}{ Weight (Kg) } \\
\hline$\leq 55$ & 8 & 40 \\
\hline$>55$ & 12 & 60 \\
\hline Total & 20 & 100 \\
\hline \multicolumn{3}{|c|}{ Education } \\
\hline $\begin{array}{l}\text { Elementary } \\
\text { School }\end{array}$ & 2 & 10 \\
\hline $\begin{array}{l}\text { Junior High } \\
\text { School }\end{array}$ & 9 & 45 \\
\hline $\begin{array}{l}\text { Senior High } \\
\text { School }\end{array}$ & 9 & 45 \\
\hline Total & 20 & 100 \\
\hline \multicolumn{3}{|c|}{ Alcohol Consumption } \\
\hline Yes & 1 & 5 \\
\hline No & 19 & 95 \\
\hline Total & 20 & 100 \\
\hline
\end{tabular}

Table 2. Duration of Benzene Exposure of Workers in a Car Painting Workshop in Surabaya 2019

\begin{tabular}{lcc}
\hline $\begin{array}{l}\text { D u r a t i o n } \\
\text { of } \quad \text { B e n e n e } \\
\text { Exposure }\end{array}$ & Frequency (n) & Percentage (\%) \\
\hline$\leq 8$ hours/day & 14 & 70 \\
$>8$ hours/day & 6 & 30 \\
\hline Total & 20 & 100 \\
\hline
\end{tabular}

some others worked for $>8$ hours/day accounting for $30 \%$.

SGOT and SGPT are biomarkers of liver function. The amount of SGOT and SGPT levels for each person was also different which can be caused by several factors. SGOT and SGPT examinations were carried out at the Nutrition Laboratory of Universitas Airlangga. Based table 3, the results of laboratory tests with blood samples as a whole showed normal levels of SGOT and SGPT. However, the results also showed that 3 people had SGOT levels exceeding the normal limit (15\%), and 6 people had SGPT levels exceeding the normal limits $(30 \%)$.

Duration of benzene exposure, weight, alcohol consumption. SGOT and SGPT levels had nominal data scale. Therefore, statistical analysis in this study used Fisher's Exact test. Meanwhile, the education variable had an ordinal data scale so that it used the contingency coefficient test. 
Table 3. Levels of SGOT and SGPT of Workers in a Car Painting Workshop in Surabaya 2019

\begin{tabular}{lccc}
\hline $\begin{array}{l}\text { Varia b l e } \\
\text { Dependent }\end{array}$ & $\begin{array}{c}\text { N o r m a I } \\
\text { Level Limit }\end{array}$ & $\begin{array}{c}\text { Frequency } \\
\text { (n) }\end{array}$ & $\begin{array}{c}\text { Percentage } \\
\text { (\%) }\end{array}$ \\
\hline Level of & $\leq 40 \mathrm{U} / \mathrm{L}$ & 17 & 85 \\
SGOT & $>40 \mathrm{U} / \mathrm{L}$ & 3 & 15 \\
\hline Total & & 20 & 100 \\
\hline Level of & $\leq 35 \mathrm{U} / \mathrm{L}$ & 14 & 70 \\
SGPT & $>35 \mathrm{U} / \mathrm{L}$ & 6 & 30 \\
\hline Total & & 20 & 100 \\
\hline
\end{tabular}

Table 4. Statistic Test

\begin{tabular}{lcc}
\hline \multicolumn{1}{c}{ Variable } & P-Value \\
\cline { 1 - 2 } \multicolumn{1}{c}{ Independent } & Dependent & \\
\cline { 1 - 1 } $\begin{array}{l}\text { Duration of benzene } \\
\text { exposure }\end{array}$ & & 0.202 \\
Weight & SGOT & 1.000 \\
Education & & 0.199 \\
Alcohol Consumption & & 1.000 \\
\hline $\begin{array}{l}\text { Duration of benzene } \\
\text { exposure }\end{array}$ & & 0.303 \\
Weight & SGPT & 1.000 \\
Education & & 0.182 \\
Alcohol Consumption & & 1.000 \\
\hline
\end{tabular}

Table 4 shows the results of the statistical test of the relationship between independent and dependent variables (p-value). It shows the relationship between the duration of benzene exposure with SGOT levels (0.202) and SGPT levels (0.303), the relationship between weight with SGOT levels (1.000) and SGOT levels (1.000), the relationship between education with SGOT level (0.199) and SGPT levels (0.812), and the last the relationship between alcohol consumption with SGOT levels (1.000) and SGPT levels (1.000).

\section{DISCUSSION}

Informal industry is a small-scale industry that produces and distributes items or services. There are many types of informal industries such as car painting workshops. A car painting workshop is a job in the service sector in the form of car maintenance. The car painting workshop located in Surabaya is a car repair shop with a total of 20 male workers. This car painting workshop has a long process, starting from problem identification, caulking, welding, primer, washing, PU paint coating, oven painting to finishing. The workers were divided into three types of work, namely caulking, welding, and painting. The car painting workshop in Surabaya is an industry that cannot be separated from the exposure to benzene. Painting is a type of work that is the primary source of benzene exposure which comes from paints used with thinner mixtures. In the car painting workshop, are two types of painting, namely indoor and outdoor painting. The different types of paintings are is based on the drying process, where the indoor process uses an oven and the outdoor process uses sunlight.

Informal industry is different from the formal industry. One the difference is in the knowledge and obedience of workers in the use of PPE. The informal industry is an industry that requires more attention because in the informal industry there are still many workers who do not know and pay attention to the risks of a job, especially the causes and effects of chemicals. In the carpainting workshop, workers will be faced with the chemical benzene that comes from thinner. Lack of understanding and ignorance of chemical substances can lead to higher susceptibility of car painting workshop workers in Surabaya. According to Aksoy (2017), thinners used in paints can contain $94 \%$ benzene. Therefore, the high content of benzene requires greater caution on the part of workers to minimize their exposure to benzene. In addition, several other chemicals contained in the thinner are toluene, xylene, and lead.

A car painting workshop in Surabaya needs to measure benzene concentrations to determine and minimize exposure. Measurement of benzene concentrations at the car painting workshop in Surabaya using the NIOSH 1501 method with gas chromatography techniques was carried out by the Technical Implementation Unit for Occupational Safety and Health. The results showed that there were 6 workers $(30 \%)$ who worked more than 8 hours/day. The use of thinner resulted in high benzene concentrations of more than $0.5 \mathrm{ppm}$ at two locations. The results of this study also indicated that in a car painting workshop in Surabaya there were some conditions that are not in accordance with the guidelines that have been set according to the Minister of Health No 70 of 2016 which stated that the TLV for benzene in the workplace is $0.5 \mathrm{ppm}$ with a time of no more than $0.5 \mathrm{ppm}$. of 8 hours/ day or 40 days/week. Therefore, industrial owners need to pay attention to this because benzene is one of the toxic substances that needs attention. Several other informal industries which have exposure to benzene are sandal/shoe workshops, printing houses, 
motorcycle repair shops, and several jobs that use other benzene products (Aksoy, 2017).

Benzene enters the body through 3 routes, namely inhalation, ingestion, and skin. In the car painting workshop, benzene compounds have the main route through inhalation. This is due to the volatile nature of benzene and the spraying technique used in the work process at the Surabaya car painting workshop. Benzene is a volatile compound that can easily enter the body. The use of the spray technique in the painting process that produces aerosol vapor is also one of the factors that make it easier for these substances to enter the body through the inhalation route, especially in workers who do not use PPE such as masks. Based on the hierarchy of control, PPE is the last alternative that can be selected to control hazards in the industry. PPE is a tool that can protect oneself from something dangerous and minimize disturbance due to the existing hazards. Research in Cairo stated that inadequate use of personal protective equipment (PPE) triggers the risk of exposure to chemicals that can threaten health due to exposure to car spraying (Mersal, 2018). Knowledge of workers is a supporting factor in work safety to prevent and control health hazards. Research by Patil et al. (2016) in India proved that the existence of a teaching program on the prevention and control of health hazards was effective in increasing the knowledge of workers.

Benzene that enters the body will be metabolized in the liver (Aksoy, 2017). The liver is an organ that has an important role in the body. Nothing can replace its role. Therefore, the health of the liver needs to be maintained. Benzene is a toxic compound so that in the metabolic process it will be oxidized with the help of enzymes that are typical for toxic substances, which is CYP2E1, so as to produce free radicals in the form of benzene oxide (Tirosh, 2015). Benzene that enters the body experience 2 possible changes, which are reduced toxin properties and increased toxin properties. Several liver diseases are caused by exposure to benzene, such as hepatocellular (HCC) and toxicantassociated fatty liver diseases (Colombo et al., 2019). Longer exposure to benzene will affect the accumulation of benzene in the body (Muslih, Sugiharta and Tualeka, 2020). Darwis, Mubarak and Anita (2017) research showed relationship between the duration of exposure per day to the concentration of benzene with $\mathrm{p}$-value $<0.05$.

Benzene is a compound that can cause various health problems such as liver dysfunction. Liver dysfunction examination can be seen from several parameters, two of are SGOT and SGPT. SGOT and SGPT are biomarkers of basic examination that must be done to see liver function (Ola and Sofolahan, 2021). An increase in one or both of them indicates a health problem in liver function (Rosida, 2016). However, according to Burt, Ferrell, and Hübscher (2017), SGPT is more specific than SGOT because the presence of this enzyme is more significant in the liver compared to SGOT which can still be found in several organs. If there is an increase in the levels of SGOT and SGPT, other tests need to be taken such as Alkali phosphate (ALP), y-Glutamyltransferase, Bilirubin, Petrobhin and Serum Albumin to find out more clearly about impaired liver function (Burt, Ferrell, and Hübscher, 2017).

Benzene is a toxic substance that gets metabolized in the liver and causes toxicity. Toxicity can be defined as the provisions and mechanisms of a substance that can create a toxic effect on living things such as humans and biological systems. One way that can be known from the mechanism of the toxicant effects is the occurrence of subcellular changes. Benzene toxicity can cause an increase in free radicals in the body. The increase in free radicals is affected by the duration of benzene. Free radicals in the body will affect the increase in lipid peroxide and liver-specific biomarkers such as SGOT and SGPT (Ola and Sofolahan, 2021). In addition, Lang (2018) also stated that benzene could affect lipid and glucose regulatory genes due to over-exposure, causing an increase in transaminase enzymes.

SGOT and SGPT measurements were carried out by taking blood samples. The reason for this is that SGOT and SGPT will be detected in the bloodstream. Someone who has liver damage will cause the release (circulation) of the SGOT and SGPT enzymes which later enter the bloodstream (Alfadaly et al., 2016). The results in Table 3 show that 17 people had normal SGOT levels (85\%), and 3 people had levels of SGOT more than the normal limit (15\%). In addition, 14 people had normal SGPT levels (70\%), and 6 people had SGPT levels more than the normal limit (30\%). Workers who had SGOT and SGPT levels more than normal limits required special attention and further examination of liver dysfunction.

The results of the study in Table 4 with Fisher's Exact test stated that there was no relationship between the duration of benzene exposure (hours/ day) with SGOT and SGPT levels in car painting workshop workers in Surabaya with p-value $>0.05$. 
This study is not in line with research conducted on farmers exposed to benzene which stated that the frequency of exposure per/day could affect the increase in SGOT and SGPT levels (Tsani, Setiani, and Dewanti, 2017). Susiwati (2017) research conducted on street sweeper workers who were exposed to pollutants containing benzene showed a significant relationship between the length of exposure to SGPT levels. Another study also showed that the duration of benzene affected the increase in SGOT and SGPT levels. This is in line with the results showing an increase in SGOT and SGPT activity in acute and chronic models due to benzene exposure. In the acute model, the increase in SGOT and SGPT was followed by the duration of benzene $(31.3 \%, 93.4 \%$, and $148.9 \% ; 10.8 \%, 26.9 \%$, and $58.9 \%$, respectively). In addition, the chronic model also showed the same gradual increase in SGOT $(46.0 \%, 48.5 \%$ and $96.2 \%)$ and SGPT $(24.7 \%$, $49.8 \%$ and $60.9 \%$ ) (Martínez-rodríguez et al., 2018).

Concentration of benzene is one of the factors that cause differences in results. The higher the concentration of benzene, the higher the possibility of benzene exposure to enter the body. The concentration of benzene differs according to the workplace. According to Chaiklieng et al. (2019) in his research, fueling workers had the highest health risk from exposure to benzene. It is because the gasoline refueling workers inhaled fuel vapor directly. In addition, workers were also exposed to benzene from vehicle emissions in their work environment which could not be separated from the vehicles, either motorcycles or cars. In addition, workspace conditions such as ventilation, temperature, and dampness need attention. In this study, ventilation already existed in the indoor painting, caulking and welding rooms, resulting in low concentrations of benzene. Research conducted at a shoe workshop in Sukajaya also showed that the presence of ventilation as well as the maintenance of temperature and humidity, resulting in low concentrations of benzene in the work environment (Fatimah, Utomo and Acid, 2020).

Differences in research results can also be linked to worker's characteristics (Febriantika et al., 2017). Each worker has different characteristics. Therefore, the differences in these characteristics need to be tested for the relationship to support the existing results. Characteristics are also an assessment to determine whether exposure to benzene as a toxic substance poses a risk or not to the body (Zuhro,
Tualeka and Harsetianingrum, 2018). The results of the research on the relationship between workers' characteristics with SGOT and SGPT levels in Table 4 showed that weight, education and alcohol consumption had no relationship with SGOT and SGPT levels. This research is in contrast to several other studies. Makaminan (2017) research stated that there was a relationship between overweight and levels of SGOT (0.024) and SGPT (0.003) enzymes. Furthermore, excess weight is the beginning of the accumulation of excess fat in the body, which will have an impact on the occurrence of overweight and obesity (Praditasari and Sumarmik, 2018). Obesity can cause metabolic syndrome resulting in insulin resistance which affects the decrease in the liver metabolic system (Lang and Beier, 2018). Therefore, if there is exposure to benzene, there will be a decrease in excretion, causing benzene to be a toxic substance in the body. Further measurements to find out whether someone is obese can be conducted using BMI. In measuring BMI there are 2 components to be paid attention, namely weight and height. According to the Minister of Health 2019, the BMI of an obese person is $>25$.

Education can shape humans towards a better direction in various aspects. Education is one of the different characteristics possessed by a person. Education is directly proportional to knowledge. The higher a person's education, the more knowledge or knowledge he gets (Putra, Setyowati and Apriyanto, 2019). Furthermore, education plays an important role in the world of behavior. This is because the more knowledge a person gains in education, the more they will know what preventive measures must be taken to avoid fatal things such as health problems (Nourian et al., 2020). In this study, it was found that the highest education of workers was Senior High School education (45\%). The statistical test regarding education with levels of SGOT and SGPT in Table 4 showed that there was no relationship. This is inversely proportional to the Maliga and Rafi'ah (2021) research conducted on farmers in the use of pesticides which stated that lower education had an effect on increasing levels of SGOT and SGPT. This is because the lack of education has an impact on the lack of understanding of the use of PPE so that farmers do not use PPE, which causes an increase in the toxicity of chemicals from pesticides and have an impact on increasing levels of SGOT and SGPT.

Life style is one of the different types of characteristics. One of person's lifestyles is 
consuming alcohol. Based on Table 4 regarding statistical tests, it was found that there was no relationship between alcohol consumption and levels of SGOT and SGPT. The result of this research is in contrast to several other studies. According to several studies, alcohol is a driving factor in increasing SGOT and SGPT levels. Meanwhile, in this study, the dominant number of workers did not consume alcohol. Research by Lohar and Langthasa (2017) showed a significant increase in SGOT and SGPT levels in individuals with alcohol drinking habits. The different research results is likely to occur because in this study the majority did not consume alcohol (95\%) so that the results of the study were inversely proportional to those of other studies.

In addition to the duration of benzene exposure in hours/day, the working period is one of the factors that need to be considered. A work period is a unit of exposure time calculated during work in years. Therefore, the longer a person works in the environment of toxic substances, the higher the the accumulation of these toxic substances that have an impact on health. Another factor that can affect the increase in SGOT and SGPT levels is a history of diseases such as diabetes, hepatitis, and autoimmune (Burt, Ferrell, and Hübscher, 2017).

\section{CONCLUSION}

of the results of the study showed that there were workers who worked $>8$ hours/day as many as 6 people (30\%). The results of the analysis showed that there was no relationship between the duration of benzene exposure (hours/day) with SGOT and SGPT levels in car painting workshop workers in Surabaya with p-value $>0.05$. In addition, the characteristics of workers (weight, education and alcohol consumption) are also not related to levels of SGOT and SGPT.

\section{ACKNOWLEDGEMENTS}

The authors would like to thank the car painting workshop in Surabaya, East Java Indonesia. The authors would also like to express great gratitude to the Faculty Health, Universitas Airlangga.

\section{REFERENCES}

Aksoy, M. (2017) Benzene Carcinogenicity. Boca Raton: CRC Press.
Alfadaly, N. et al. (2016) 'Toxicological Study on the Health Effects of Long Term Exposure To Benzene in Benzene Filling Workers, Qassim Region, Ksa', The Egyptian Journal of Forensic Sciences and Applied Toxicology, 16(1), pp. 81-94.

Alshareef,A. A. and Ibrahim, M. (2020a) 'Neurological and Biological Toxicity of Subchronic Exposure to Benzene in Male Rats', Journal Biochem Technolgy, 11(2), pp. 52-59.

Alshareef, A. A. and Ibrahim, M. (2020b) 'Probable Toxicity of Benzene Inhalation on Nervous System and Blood Image of Gas Station Workers', Journal Biochem Technolgy, 10(2), pp. 71-76.

Bestari, E. M., Sudarmaji and Sulistyorini, L. (2019) 'Bengkel Motor Ahass Kota Kediri', Jurnal Kesehatan Lingkungan, 11(4), pp. 293-299.

Burt, A., Ferrel R.D., and Hübscher, S.G. (2017) MacSween's Pathology of the Liver. 7th Edition. China: Elsevier Ltd.

CDC (2018) Fact of Benzene, U.S Departement of Health and Human Service.

Statistics Indonesia (2020) Agustus 2020: Tingkat Pengangguran Terbuka (TPT) sebesar 7,07 persen. Jakarta: Statistic Indonesia

Chaiklieng, S. et al. (2019) 'Factors Affecting Urinary tt-Muconic Acid Detection among benzene Exposed Workers at Gasoline Stations', International Journal of Environmental Research and Public Health, 16(4209), pp. 1-11.

Colombo, M. et al. (2019) 'EASL Clinical Practice Guideline: Occupational liver diseases', Journal of Hepatology, 71(5), pp. 1022-1037.

D’Andrea, M. A. and Reddy, G. K. (2018) ‘Adverse Health Complaints of Adults Exposed to Benzene After a flaring Disaster at the BP refinery Facility in Texas City, Texas', Disaster Medicine and Public Health Preparedness, 12(2), pp. 232240.

Darwis, D., Mubarak, M. and Anita, S. (2017) 'Risiko Paparan Benzena Terhadap Kandungan Fenol Dalam Urin Pekerja Pengecatan Mobil Di Kecamatan Tampan Kota Pekanbaru Tahun 2017', Dinamika Lingkungan Indonesia, 5(1), pp. $40-47$.

Fatimah, R., Utomo, S. W. and Acid, S. (2020) 'Stres Oksidatif Pada Pekerja Yang Terpajan Benzena Melalui Pengukuran Plasma Malondialdehid (Mda) (Studi Kasus Pada Pekerja Bengkel Sandal / Sepatu Di Desa Sukajaya, Kecamatan Tamansari, Kabupaten Bogor Tahun 2018)', Jurnal Kesehatan Masyarakat (HEARTY), 8(1), pp. 9-19. 
Fayed, et. al. (2017) 'Phenotype Analysis of Lymphocytes in Workers with Chronic Benzene Exposure', Immunology Letters, 42(4), pp. 161-168..

Febriantika, D., Sulistiyani and Budiyono (2017) 'Analisis Risiko Kesehatan Pajanan Benzena di Industri Percetakan X Kota Semarang', Jurnal kesehatan masyarakat, 5(1), pp. 430-437.

Hämäläinen, P., Takala, J. and Kiat, T. B. (2017) Global Estimates of Occupational Accidents and Work-related Illnesses 2017. Singapore: Workplace Safety and Health Institute.

Lang, A. L. and Beier, J. I. (2018) 'Interaction of Volatile Organic Compounds and Underlying Liver Disease: a New Paradigm for Risk Anna', Biological Chemistry, 399(11), pp. 1237-1248.

Lohar, M. and Langthasa, P. (2017) 'An investigative study in Dima Hasao District, Assam : Study of Association of Alcoholic Drink and ALD using Three Biomarkers of', Journal of Biotechnology and Biochemistry, 3(3), pp. 12-14. 4.

Lu, P. C. W., Shahbaz, S. and Winn, L. M. (2020) 'Benzene and Its Effects on Cell Signaling Pathways Related to Hematopoiesis and Leukemia', Journal of Applied Toxicology, 40(8), pp. 1018-1032.

Makaminan, M. A. (2017) 'Gambaran Kadar Enzim Hati pada Pegawai dengan berat Badan Overweight berdasarkan Indeks Masa Tubuh (IMT) di Lingkungan Kerja Poltekkes Kemenkes Manado Tahun 2016', Jurnal Gizido, 9(1), pp. 2-10.

Maliga, I. and Rafi' ah (2021) 'Hubungan Penggunaan Alat Pelindung Diri (APD) dengan Kadar Sgot Dan SGPT Dalam Darah Pada Petani Padi', 20(1), pp. 174-181.

Martínez-rodríguez, J. L. et al. (2018) 'Quantitative measurement of Oxidative Damage in Erythrocytes as Indicator in Benzene Intoxicatios', Toxicology Mechanisms and Methods, 28(6), pp. 450-460.

Mersal, F. A. (2018) 'Structured Teaching Program on Occupational Health Hazards among Painting Workers at Elherafeyien City in Cairo', Journal of Biomedicine and Nursing, 4(3), pp. 1-11.

Minister of Health (2016) 'PERMENKES 70/2016 Tentang Standar dan Persyaratan Kesehatan Lingkungan Kerja Industri’. Jakarta: Minister of Health.

Minister of Manpower (2018) 'PERMENAKER 05/2018 Tentang Keselamatan dan Kesehatan Kerja Lingkungan Kerja'. Jakarta: Minister of Manpower.
Minister of Health (2019) Batas Ambang Indeks Massa Tubuh (IMT). Jakarta: Minister of Health

Muslih, A., Sugiharta, B. and Tualeka, A. R. (2020) 'Evaluation to Identify Benzene Safe Concentration in Oil and Gas processing Facility in East Java Area Due to Process Fugitive Emission', Indian Journal of Forensic Medicine \& Toxicology, 14(1), pp. 142-147.

Nasional Institute for Occupational Safety and Health (NIOSH) (2019) CIB 69: NIOSH Practices in Occupational Risk Assessment. Cincinnati, Ohio.

Nourian, M. et al. (2020) 'Effect of Lifestyle Modification Education based on Health Belief Model in Overweight/Obese Patients with Non-Alcoholic Fatty Liver Disease: A Parallel Randomized Controlled Clinical Trial', Clinical Nutrition ESPEN, 38(4), pp. 236-241.

Ola, O. S. and Sofolahan, T. A. (2021) 'A monoterpene antioxidant, linalool, mitigates benzene-induced oxidative toxicities on hematology and liver of male rats', Egyptian Journal of Basic and Applied Sciences, 8(1), pp. 39-53.

Patil, S. D. et al. (2016) 'A study to Assess Knowledge on Occupational Health Hazard among the workers of Jaggery factory with Special Emphasis to Prepare Health Educational Material in Selected Jaggery Factories at Kolhapur, India', International Journal of Innovative Research and Development, 5(6), pp. 124-132.

Praditasari, J. A. and Sumarmik, S. (2018) 'Fat Intake, Physical Activity and Obesity among Adolescent Girls in SMP Bina Insani Surabaya', Media Gizi Indonesia, 13(2), pp. 117-122.

Putra, T. I., Setyowati, N. and Apriyanto, E. (2019) 'Identifikasi Jenis dan Pengelolaan Limbah Bahan Berbahaya dan Beracun Rumah Tangga:Studi Kasus Kelurahan Pasar Tais Kecamatan Seluma Kabupaten Seluma', Jurnal Penelitian Pengelolaan Sumber Daya Alam dan Lingkungan, 8(2), pp. 49-61.

Rosida, A. (2016) 'Pemeriksaan Laboratorium Penyakit Hati', Berkala Kedokteran, 12(1), pp. 123-131.

Sari, D. F. and Suryani, F. (2018) 'Manajemen Risiko Kesehatan Dan Keselamatan Kerja Pelaksanaan Konstruksi Oil Dan Gas Dengan Metode Hazard Identification', Ikraith-Teknologi, 2(1), pp. $15-19$.

Setyawati, I. and Anggraeni, R. (2018) 'Effectiveness of Sweet Orange Peel Extract (Citrus Sinensis) on 
the Improvement of Liver Functions of Animal Trials Induced by Cigarette Smoke', Journal of Young Pharmacists, 10(2), pp. s132-s135.

Susiwati, A. (2017) 'Correlation with Long Term of Pattern Exposure to SGPT Response on Street Sweeper in Afternoon Days in Bengkulu City', Journal of Nursing and Public Health, 5(2), pp. 95-100.

Tirosh, O. (2015) Liver Metabolism and Fatty Liver Disease. Boca Raton: CRC Press.

Tsani, R. A., Setiani, O. and Astorina, N. (2017) 'Hubungan Riwayat Pajanan Pestisida Dengan Gangguan Fungsi Hati Pada Petani Di Desa Sumberejo Kecamatan Ngablak Kabupaten
Magelang', Jurnal Kesehatan Masyarakat (e-Journal), 5(3), pp. 411-420.

Zeverdegani, S. K, Barakat, S. and Yazdi, M. (2016) 'Evaluation of Organic Solvents Effects on Physiological Parameters of Exposed People in Industry', Journal of Occupational Hygiene Engineering, 3(2), pp. 21-26.

Zuhro, R., Tualeka, A. R. and Harsetianingrum, R. A. (2018) 'Determination of the Safe Duration of Benzene Non-Carcinogenic Exposure in Motor Workshop Area', Indian Journal of Forensic Medicine \& Toxicology, 9(10), pp. 283-287. 